\section{Osmotic treatment, growth regulator and rooter in Tabebuia roseoalba (RIDL.) Sandwith seeds for direct sowing}

\author{
Alexandre Carneiro da Silva ${ }^{1 *}\left(\mathbb{D}\right.$, Maiara Pilar Palmeira da Silva ${ }^{3}$, Rayssa \\ Zamith $^{4}\left(\mathbb{D}\right.$, Gustavo Galetti ${ }^{4}$ iD , Fatima Conceição Márquez Piña-Rodrigues ${ }^{2}$ iD
}

ABSTRACT: Direct seeding is a technology that reduces the costs of forest restoration projects and favors species which are difficult to establish for seedlings. The seeds osmotic treatment to accelerate and standardize germination and induce tolerance to environmental stresses may favor seedling establishment in field through direct sowing and contribute to the greater efficiency of this technique. With the purpose of favor seed germination and seedling establishment under direct seeding conditions in the field, Tabebuia roseoalba osmoprimed seeds in polyethylene glycol (PEG) solution and unconditioned seeds were treated with isolated and/or combined solutions of plant growth regulators (PGR) and rooting (RTG). These seeds were submitted to germination test and evaluated for percentage germination rate, germination speed index and normal seedlings, and to seedling emergence test by direct field seeding. RTG had a toxic effect on T. roseoalba seeds. Osmoconditioning induced stress tolerance by RTG during germination and on seedling establishment. PGR treatment favors seedling emergence in field conditions and alleviates the toxicity effect caused by RTG. These treatments have great potential for use in direct sowing of $T$. roseoalba seeds.

Index terms: osmopriming, phytohormones, forest restoration, seedling establishment, stress tolerance.

Tratamento osmótico, reguladores de crescimento e enraizador em sementes de Tabebuia roseoalba (RIDL.) Sandwith para semeadura direta

RESUMO: A semeadura direta é uma tecnologia que reduz os custos de projetos de restauração florestal e favorece espécies de difícil estabelecimento por mudas. $\mathrm{O}$ tratamento osmótico de sementes para acelerar, uniformizar e induzir tolerância a estresses ambientais durante a germinação pode favorecer o estabelecimento de plântulas em campo, por meio da semeadura direta e contribuir para a maior eficiência dessa técnica. Com o objetivo de favorecer a germinação de sementes e o estabelecimento de plântulas em condições de semeadura direta em campo, sementes de Tabebuia roseoalba osmocondiocionadas em solução de polietilenoglicol (PEG) e sementes não condicionadas foram tratadas com soluções isoladas e/ou combinadas de reguladores de crescimento vegetal (PGR) e de enraizantes (RTG). Essas sementes foram submetidas ao teste de germinação e avaliadas quanto à porcentagem de germinação, índice de velocidade de germinação e plântulas normais e ao teste de emergência de plântula, por meio de semeadura direta em campo. O RTG teve um efeito tóxico nas sementes de T. roseoalba. O osmocondicionamento induziu tolerância ao estresse por RTG durante a germinação e o estabelecimento de plântulas. $O$ tratamento com PGR favorece a emergência de plântulas em condições de campo e alivia o efeito da toxicidade causada pelo RTG. Esses tratamentos têm grande potencial de uso na semeadura direta de sementes de T. roseoalba.

Termos para indexação: osmocondicionamento, fitormônios, restauração florestal, estabelecimento de plântulas, tolerância a estresse.
Journal of Seed Science, v.42, e202042022, 2020

http://dx.doi.org/10.1590/2317$1545 v 42226945$
$*$ Corresponding author:
E-mail: alexandre.silva@ifac.edu.br

Received: 8/1/2019. Accepted: 2/21/2020.

${ }^{1}$ Instituto Federal de Educação, Ciência e Tecnologia do Acre, 69970000 - Tarauacá, AC, Brasil.

${ }^{2}$ Universidade Federal de São Carlos, Departamento de Ciências Ambientais, 18052-780 - Sorocaba, SP, Brasil.

${ }^{3}$ Universität zu Köln, Botanisches Institut-50674 Köln, NRW, Germany.

${ }^{4}$ Universidade Federal de São Carlos, Programa de Pós-Graduação em Ciências Ambientais, 13565-905 São Carlos, SP, Brasil. 


\section{INTRODUCTION}

Seedling establishment is one of the most critical and vulnerable processes for plant life and often represents a challenge after emerging from the protected environment of the seed (Gommers and Monte, 2018). It is a critical step for the regeneration of plant populations, because of the common high mortality rates during this stage (Grubb, 1977; Harper, 1977; Clark et al., 1999). In plant species with a wide distribution, the populations are usually subjected to different biotic and abiotic conditions and, therefore, to environments with contrasting limitations on the seedling establishment (Castro et al., 2004).

Tabebuia roseoalba (Ridl.) Sandwith (Bignoniaceae) is an endangered tropical tree species, with a wide geographic distribution in South America. In Brazil, it is mostly found in Seasonal Semideciduous Atlantic Forest and in Savanna (Feres et al., 2012). It has large commercial, medicinal and ornamental value, with widespread use in urban forestry and plant recovery of degraded areas. Their seeds, currently classified as orthodox, displays a strong variation in quality during storage and a short period of viability, which hampers its natural dispersal as well as the development of cropping techniques for this tree (Lorenzi, 2009).

Reforestation usually falls into three main categories: assisted natural regeneration, direct seeding, and planting seedlings by tubestock (Greening Australia Victoria, 2003). The choice between different restoration strategies depends in part on a compromise between effectiveness and cost (Prieto-Rodao et al., 2019). In recent years, direct seeding of native trees has been used as a low-cost alternative for restoration (Engel and Parrotta, 2001; Wallin et al., 2009; Ceccon et al., 2016). Direct seeding involves applying seed propagules directly into the soil where reforestation is required without first germinating seeds off-site (Schirmer and Field, 2000; Summers et al., 2015).

Direct seeding is considered a feasible alternative for large-scale forest restoration (Freitas et al., 2019). It has as advantages the reducing costs in the implementation of forest restoration projects by exempting the use of nurseries, providing successful establishment of species with difficulty to produce seedlings, growing in definitive location, and reducing losses of sensitive species to transplant shock (Pancel, 1993; Ferreira et al., 2007; Cole et al., 2011). However, the chances of survival of the plant in direct seeding are less than planting seedlings, because they are unprotected against lethal agents controlled in the greenhouse stage (Smith, 1986).

Osmopriming is a pre-sowing treatment defined as the controlled hydration of seeds by exposure to osmotic solutions up to a limit that allows pre-germination metabolic events to proceed without visible protrusion of the radicle (Heydecker and Coolbear, 1977; Bradford, 1986; Jisha et al., 2013). This treatment improves germination efficiency and seedling emergence under adverse environmental conditions as drought (Wang et al., 2003; Jisha et al., 2013) and salinity (Sivritepe et al., 2003; Jisha et al., 2013), and improve the resistance or tolerance to elevated temperatures (Ligterink et al., 2007).

Plant growth regulators (PGRs) were used to improve seeds germination, seedling establishment and induce tolerance to diverse environmental stress in these stages and during plant growth (Riefler et al., 2006; Wen et al., 2010; Peleg and Blumwald, 2011; Shinohara et al., 2017). PGRs were associated with micronutrients, which act primarily as enzyme catalysts by seed coating, seeking higher germination values and better establishment of plants in the field (Silva et al., 2008). The aim of this work was to evaluate osmopriming combined with the use of plant growth regulators, rooting and seed coating with polymers in the treatment of Tabebuia roseoalba seeds to favor seed germination and the establishment of seedlings under direct sowing conditions in the field.

\section{MATERIAL AND METHODS}

Freshly harvested T. roseoalba seeds from forest fragment located in the municipality of Promissão, São Paulo State, were used. The water content in wet basis and a mass of one thousand seeds were obtained (Brasil, 2009). During the experiment the seeds were stored at $5{ }^{\circ} \mathrm{C}$ in hermetic plastic packaging.

The osmopriming was performed by seeds imbibition in osmotic polyethylene glycol (PEG) 6000 solution with hydric 
potential $(\psi \mathrm{w})$ of $-0.8 \mathrm{MPa}$ at $25^{\circ} \mathrm{C}$, calculated according to the equation proposed by Michel and Kaufmann (1973), during $18 \mathrm{~h}$. The choice of hydric potential and treatment time was determined based on previous imbibition curves established with $0.0 \mathrm{MPa}$ (deionized water) and -0.8 MPa (PEG solution) at $25^{\circ} \mathrm{C}$. Each curve's point was obtained of three independent replicates of fifteen seeds, seeded in Petri dishes ( $9 \mathrm{~cm}$ diameter), between two sheets of paper, moistened with $12 \mathrm{~mL}$ of water or PEG solution with the photoperiod of sixteen hours of light. After different imbibition times, the seeds were weighed ( $0.0001 \mathrm{~g}$ precision) to obtain the wet mass (gravimetric method), and the water content was calculated. After osmopriming, the seeds were washed in running water to remove the PEG residues and placed to dry for $72 \mathrm{~h}$ in controlled atmosphere of $42 \% \mathrm{RH}$, at $25^{\circ} \mathrm{C}$ (Buitink et al., 2003; Silva et al., 2017).

Osmoprimed and unprimed seeds were submitted to treatments with plant growth regulators (PGRs) $(0.009 \%$ kinetin, $0.005 \%$ gibberellic acid, $0.005 \%$ indolbutyric acid) and/or rooting (RTG) (1.5\% water soluble nitrogen, $6 \%$ organic carbon, $0.2 \%$ boron). The following treatments were established: i - control (without PGRs or RTG); ii - RTG; iii - PGRs; iv - RTG + PGRs. For each treatment, $2 \mathrm{~mL}$ of PRGs and/or $2 \mathrm{~mL}$ of RTG were used, and $1 \mathrm{~mL}$ of a polymer (Polifix $\left.\mathrm{G}^{\circ}\right)$ and water were added until the final solution volume of $10 \mathrm{~mL}$ was complete. The proportion of $10 \mathrm{~mL}$ of the final solution per $100 \mathrm{~g}$ of seed was applied. After that, the seeds and solutions were placed in a plastic bag and mixed by gentle shaking for three minutes, and then the seeds were left to dry at room temperature for 24 hours.

The germination test was performed by four replicates of thirty seeds seeded in a roll of germinating paper, moistened with 2.5 times the volume of water in relation to the weight of the dry paper, at $25{ }^{\circ} \mathrm{C}$. The percentage of germination (G\%) and normal seedlings (NS\%) was evaluated. The seeds were considered germinated with root protrusion equal to or greater than $1 \mathrm{~mm}$. Seedlings exhibiting well-formed primary root and hypocotyl, cotyledons and leaves were classified as normal. From the daily germination count, the germination speed index (GSI) was calculated according to Maguire (1962). The direct seedling was conducted in March $13^{\text {th }}, 2016$, in an experimental area $(23,5944 \mathrm{~S}$ and 47,5234W UTM), in Sorocaba, São Paulo State. The area was a pasture covered by Brachiaria decumbens L., totally removed by manual weeding one week prior to the experiment. The soil was uniform with Eutrophic Red Latosol (LVe). The climatic conditions during the test are shown in Figure 1.

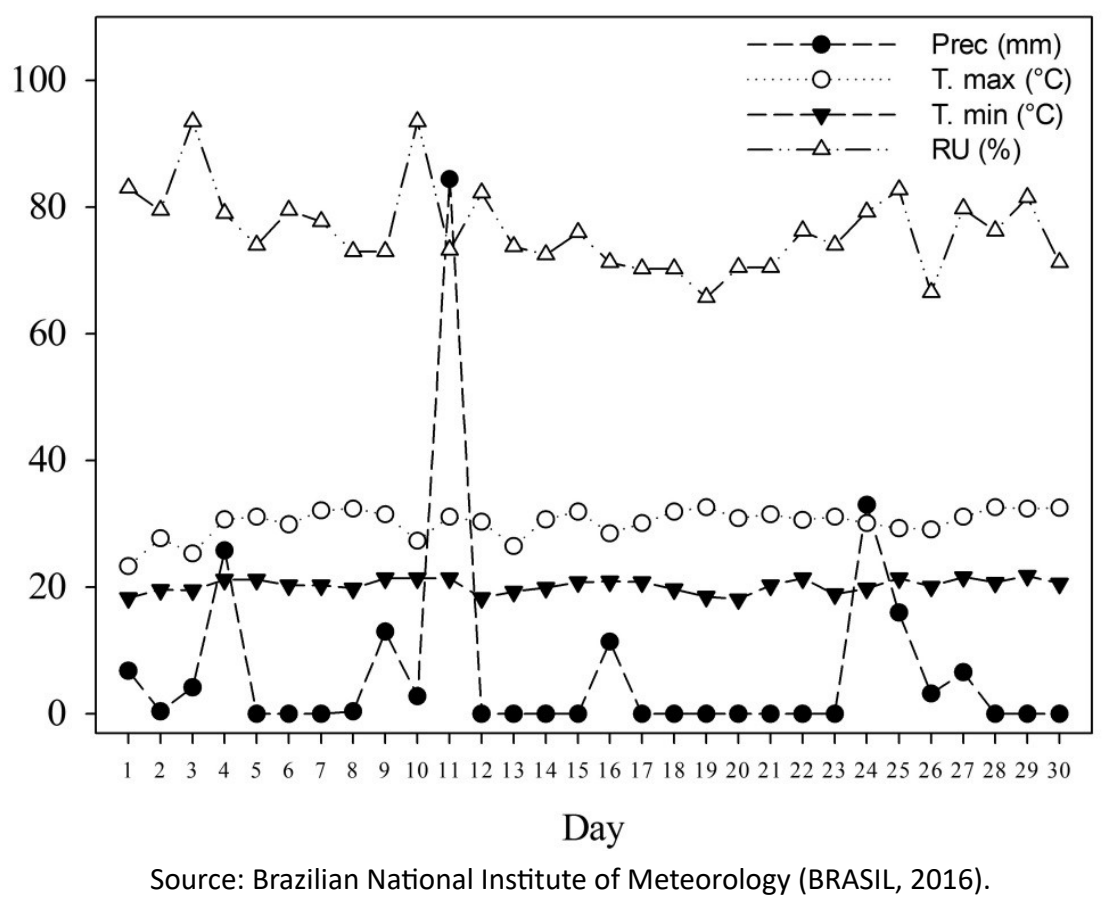

Figure 1. Minimum temperature (T. $\mathrm{min}$ ), maximum temperature (T. max), relative air humidity (RU) and precipitation (Prec). Sorocaba, São Paulo, Brazil. March 2016. 
Four experimental blocks were established, represented by four beds of $2 \times 3 \mathrm{~m}, 70 \mathrm{~cm}$ apart. In each block eight lines of $3 \mathrm{~m}$ spaced at $20 \mathrm{~cm}$ were established, in which one replication of thirty seeds for each treatment was distributed. The seeds were seeded every $10 \mathrm{~cm}$, at a depth of $1 \mathrm{~cm}$. The lines were covered with Brachiaria grass straw, $5 \mathrm{~cm}$ high (Silva et al., 2015). At fifteen days after seeded, when the emergence of seedlings ceased, the number of emerged seedlings above the straw was counted, and the percentage of seedling emergence (SE\%) was calculated.

For the G\%, NS\% and GSI analyzes, a completely randomized experimental design was adopted. For the SE\%, the randomized block design was used. Treatments were evaluated by a factorial arrangement of 2 (osmoprimed and unprimed seeds) $\times 4$ ( 3 treatments + control), with four replicates per treatment. The data normality was evaluated using the Shapiro-Wilk's test, and analysis of variance (ANOVA) was performed. The means were compared by the Tukey test $(p \leq 0.05)$. All analyses were performed using software $R(2015)$.

\section{RESULTS AND DISCUSSION}

The water seeds content found in the work lot was 9.4\%, while the mass of one thousand seeds was 0.6897g.seed ${ }^{-1}$. The beginning of germination was observed after 41 hours of imbibition in water. Seeds imbibed in osmotic solution did not germinate and maintained water content without significant variation after reaching phase II (Figure 2).

There was no significative differences in G\%, GSI, NS\% and SE\% among osmoprimed seeds. For unprimed seeds, the G\%, NS\% and GSI of the control (untreated seed) was higher than the seeds treated with PGRs and with RTG, while for SE\% the best result was observed for seeds treated with PGRs and PGRs + RTG (Figure 3).

There was no difference in G\% between unprimed and osmoprimed seeds when treated with PGRs or with PGRs + RTG. For untreated seeds (control), the osmopriming reduced G\% and GSI, whereas for seeds treated with RTG, the osmopriming provided a higher G\% and GSI. The NS\% differed when treated with PGRs + RTG, while the SE\% differed only when treated with PGRs, with best results for unprimed seeds (Figure 3).

According to imbibition curves (Figure 2), the imbibition time of the seed in osmotic solution (-0.8 MPa) during 18 $h$ meets the requirements for application of the osmopriming technique. In this condition, the imbibition of the seeds in osmotic solutions of enough hydric potential is low enough to prevent germination, but allows to occur some pregerminating physiological and biochemical processes (Heydecker and Coolbear, 1977; Bradford, 1986; Bewley et al., 2013).

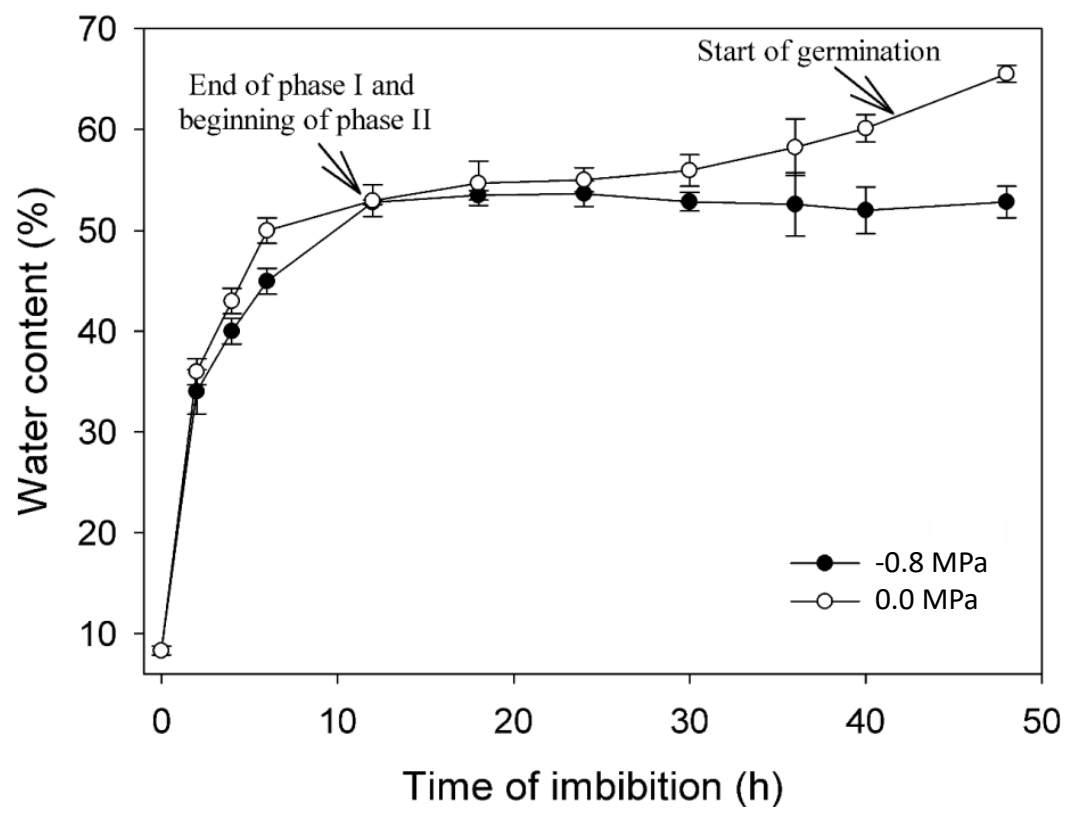

Figure 2. Imbibition curves of T. roseoalba seeds in water (0.0 MPa) and osmotic solution $(-0.8 \mathrm{MPa})$ at $25^{\circ} \mathrm{C}$. 
Considering that RTG treatment in unprimed seeds resulted in lower G\%, GSI\%, NS\% and SE\% in relation to untreated seeds (control), it is possible to infer that the rooting treatment had a toxic effect on T. roseoalba seeds, in the concentration and form utilized in this study. In favorable conditions, the osmopriming did not benefit seed germination, since for untreated seeds (control) the G\% was higher in unprimed seeds (Figure 3A). However, assuming that rooting had a toxic effect on seed germination, it follows that the osmotic conditioning induced tolerance to stress caused by rooting treatment, once the G\% and GSI for seeds treated with RTG were higher in seeds previously submitted to osmopriming (Figures $3 \mathrm{~A}$ and $3 \mathrm{~B}$ ).

During the osmopriming, the seeds are subjected to hydric stress (Ashraf et al., 2018), which produces a memory mediated by proteins and transcription factors (Bruce et al., 2007), activating networks of physiological and metabolic mechanisms for defense against the stress initially imposed. Thus, there may be an tolerance induction to other types of stresses (Genoud and Métraux, 1999; Kranner et al., 2010).

Seeds unprimed treated with RTG + PGRs showed the best results compared to osmoprimed seeds treated only with RTG for all avaliations (Figure 3), indicating that PGRs treatment alleviate the effect to rooting toxicity. Due to the potential of the osmopriming to induce stress tolerance during germination and seedling establishment, and because
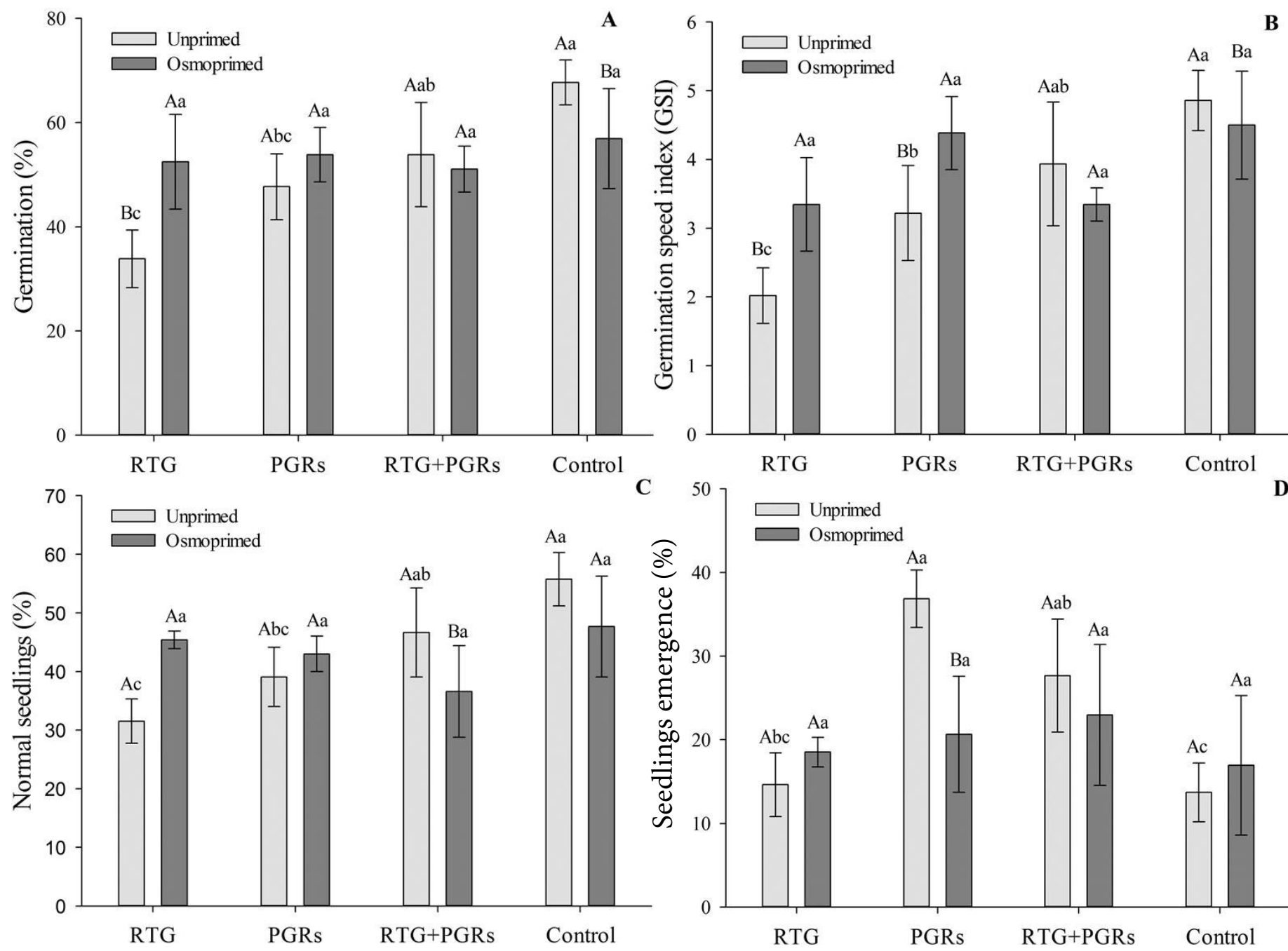

Means $\pm \mathrm{SDs}, \mathrm{n}=4$.

Different capital letters represent significant differences at $(p \leq 0.05)$ unprimed and osmoprimed seeds, submitted to the same treatment. Lowercase letters represent significant differences at $(p \leq 0.05)$ between unprimed or osmoprimed seeds, submitted to different treatments.

Figure 3. Germination (A), germination speed index (B), normal seedlings (C), and seedlings emergence (D) of $T$. roseoalba unprimed and osmoprimed seeds, treated with plant growth regulators (PGRs) and rooting (RTG). 
the PGRs treatment increased the seedling emergence and also alleviated the toxicity effect of rooting treatment observed in this study, there is great potential for use of the osmopriming and PGRs in seeds treatment for direct seedling of $T$. rosealba.

The present study provides a basis for the development of new researches to improve the techniques of osmotic conditioning, including variation in potential osmotic of the solution, time of imbibition in osmotic solution and temperature associated or not to PGRs treatments, using different doses per mass of seeds for the direct seedling of T. roseoalba in forest restoration.

\section{CONCLUSIONS}

The RTG had an apparent toxic effect on the seeds. Osmopriming induces stress tolerance to toxicity during $T$. roseoalba seed germination. PGR treatment accelerates germination and induces greater seedling emergence, favoring seedling establishment under field conditions.

\section{REFERENCES}

ASHRAF, M.A.; AKBAR, A.; ASKARI, S.H.; IQBAL, M.; RASHEED, R.; HUSSAIN, I. Recent advances in abiotic stress tolerance of plants through chemical priming: an overview. In: Advances in seed priming. Singapore: Springer, 2018. p.51-79. https://link.springer.com/ chapter/10.1007/978-981-13-0032-5_4

BEWLEY, J.D.; BRADFORD, K.J.; HILHORST, H.W.M.; NONOGAKI, H. Physiology of development, germination and dormancy. 3. ed. New York: Springer, 2013. 392p.

BRADFORD, K.J. Manipulation of seed water relations via osmotic priming to improve germination under stress conditions. HortScience, v.21, n.5, p.1105-1112, 1986.

BRASIL. Ministério da Agricultura, Pecuária e Abastecimento. Regras para análise de sementes. Secretaria de Defesa Agropecuária. Brasília: MAPA/ACS, 2009. 395p. http://www.agricultura.gov.br/assuntos/insumos-agropecuarios/arquivos-publicacoesinsumos/2946_regras_analise_sementes.pdf

BRASIL. Ministério da Agricultura, Pecuária e Abastecimento. Instituto Nacional de Meteorologia (INMET). http://www.inmet.gov. br. Accessed on April 16 $16^{\text {th }}, 2016$. BRUCE, T.J.A.; MATTHES, M.C.; NAPIER, J.A.; PICKETT, J.A. Stressful "memories" of plants: evidence and possible mechanisms. Plant Science, v.173, n.6, p.603-608, 2007. https://doi.org/10.1016/j.plantsci.2007.09.002

BUITINK, J.; VU, B.L.; SATOUR, P.; LEPRINCE, O. The re-establishment of desiccation tolerance in germinated radicles of Medicago truncatula Gaertn. seeds. Seed Science Research, v.13, n.4, p.273-286, 2003. https://doi.org/10.1079/SSR2003145

CASTRO, J.; ZAMORA, R.; HÓDAR, J.A.; GÓMEZ, J.M. Seedling establishment of a boreal tree species (Pinus sylvestris) at its southernmost distribution limit: consequences of being in a marginal Mediterranean habitat. Journal of Ecology, v.92, n.2, p.266277, 2004. https://doi.org/10.1111/j.0022-0477.2004.00870.x

CECCON, E.; GONZÁLEZ, E.J.; MARTORELL, C. Is direct seeding a biologically viable strategy for restoring forest ecosystems? Evidences from a meta-analysis. Land Degradation and Development, v.27, n.3, p.511-520, 2016. https://doi.org/10.1002/Idr.2421

CLARK, J.S.; BECKAGE, B.; CAMILL, P.; CLEVELAND, B.; HILLERISLAMBERS, J.; LICHTER, J.; MCLACHLAN, J.; MOHAN, J.; WYCKOFF, P. Interpreting recruitment limitation in forests. American Journal of Botany, v.86, n.1, p.1-16, 1999. https://doi.org/10.2307/2656950

COLE, R.J.; HOLL, K.D.; KEENE, C.L.; ZAHAWI, R.A. Direct seeding of late-successional trees to restore tropical montane forest. Forest Ecology and Management, v.261, n.10, p.1590-1597, 2011. http://www.holl-lab.com/uploads/2/6/0/0/26004460/cole_et_ al_2011__direct_seeding.pdf

ENGEL, V.L.; PARROTTA, J.A. An evaluation of direct seeding for reforestation of degraded lands in central São Paulo state, Brazil. Forest Ecology and Management, v.152, n.1-3, p.169-181, 2001. https://doi.org/10.1016/S0378-1127(00)00600-9

FERES, J.M.; SEBBENN, A.M.; GUIDUGLI, M.C.; MESTRINER, M.A.; MORAES, M.L.T.; ALZATE-MARIN, A.L. Mating system parameters at hierarchical levels of fruits, individuals and populations in the Brazilian insect-pollinated tropical tree, Tabebuia roseo-alba (Bignoniaceae). Conservation Genetics, v.13, n.2, p.393-405, 2012. https://doi.org/10.1007/s10592-011-0292-z 
FERREIRA, R.A.; DAVIDE, A.C.; BEARZOTI, E.; SOUZA-MOTTA, M. Semeadura direta com espécies arbóreas para recuperação de ecossistemas florestais. Revista Cerne, v.13, n.3, p.271-279, 2007. https://www.redalyc.org/pdf/744/74413305.pdf

FREITAS, M.G.; RODRIGUES, S.B.; CAMPOS-FILHO, E.M.; CARMO, G.H.P.; VEIGA, J.M.; JUNQUEIRA, R.G.P.; VIEIRA, D.L.M. Evaluating the success of direct seeding for tropical forest restoration over ten years. Forest Ecology and Management, v.438, p.224-232, 2019. https://doi.org/10.1016/j.foreco.2019.02.024

GENOUD, T.; MÉTRAUX, J.P. Crosstalk in plant cell signaling: structure and function of the genetic network. Trends in Plant Science, v.4, n.12, p.503-507, 1999. https://doi.org/10.1016/S1360-1385(99)01498-3

GOMMERS, C.M.M.; MONTE, E. Seedling establishment: a dimmer switch-regulated process between dark and light signaling. Plant Physiology, v.176, n.2, p.1061-1074, 2018. http://www.plantphysiol.org/content/plantphysiol/176/2/1061.full.pdf

GREENING AUSTRALIA VICTORIA. Revegetation techniques: a guide for establishing native vegetation in Victoria. Victoria, Australia, 2003. https://www.greeningaustralia.org.au/wp-content/uploads/2017/11/GUIDE_A-guide-for-establishing-native-vegetation-in-Victoria.pdf

GRUBB, P.J. The maintenance of species- richness in plant communities: the importance of the regeneration niche. Biological Reviews, v.52, n.1, p.107-145, 1977. https://doi.org/10.1111/j.1469-185X.1977.tb01347.x

HARPER, J.L. Population biology of plants. London: Academic Press, 1977. 900p.

HEYDECKER, W.; COOLBEAR, P. Seed treatments for improved performance survey and attempted prognosis. Seed Science and Technology, v.5, n.2, p.353-426, 1977.

JISHA, K.C.; VIJAYAKUMARI, K.; PUTHUR, J.T. Seed priming for abiotic stress tolerance: an overview. Acta Physiologiae Plantarum, v.35, p.1381-1396, 2013. https://link.springer.com/content/pdf/10.1007/s11738-012-1186-5.pdfdoi: 10.1007/s11738-012-1186-5

KRANNER, I.; MINIBAYEVA, F.V.; BECKETT, R.P.; SEAL, C.E. What is stress? Concepts, definitions and applications in seed science. New Phytologist, v.188, n.3, p.655-673, 2010. https://nph.onlinelibrary.wiley.com/doi/full/10.1111/j.1469-8137.2010.03461.x

LIGTERINK, W.; KODDE, J.; LAMMERS, M.; DASSEN, J.H.A.; VAN DER GEEST, A.H.M.; MAAGD, R.A.; HILHORST, H.W.M. Stress-inducible gene expression and its impact on seed and plant performance: a microarray approach. In: ADKINS, S.W.; ASHMORE, S.; NAVIE, S.C. (ed.). Seeds: biology, development and ecology. Wallingford, United Kingdom: CABI, 2007. p.139-148.

LORENZI, H. Árvores brasileiras: manual de identificação e cultivo de plantas arbóreas do Brasil, v.3. São Paulo: Instituto Plantarum, 2009. 384p.

MAGUIRE, J.D. Speed of germination-aid in selection and evaluation for seedling emergence and vigor. Crop Science, v.2, n.2, p.176$177,1962$.

MICHEL, B.E.; KAUFMANN, M.R. The osmotic potential of polyethilene glycol 6000. Plant Physiology, v.51, p.914-916, 1973. http:// www.plantphysiol.org/content/plantphysiol/51/5/914.full.pdf

PANCEL, L. Florestation. In: PANCEL, L.; KÖHL, M. (ed). Tropical forestry handbook. Springer-Verlag, 1993. p.654-725.

PELEG, Z.; BLUMWALD, E. Hormone balance and abiotic stress tolerance in crop plants. Current Opinion in Plant Biology, v.14, n.3, p.290-295, 2011. https://doi.org/10.1016/j.pbi.2011.02.001

PRIETO-RODAO, E.; RICKER, M.; SIEBE, C. A cost-benefit evaluation of direct seeding with and without protector for two native tree species in a tropical rainforest. Restoration Ecology, v.27, n.2, p.247-253, 2019. https://onlinelibrary.wiley.com/doi/epdf/10.1111/ rec. 12853

R Core Team 2015: a language and environment for statistical computing. Vienna, Austria: R Foundation for Statistical Computing, 2015. http://www.r-project.org/

RIEFLER, M.; NOVAK, O.; STRNAD, M.; SCHMÜLLING, T. Arabidopsis cytokinin receptor mutants reveal functions in shoot growth, leaf senescence, seed size, germination, root development, and cytokinin metabolism. The Plant Cell, v.18, p.40-54, 2006. http:// www.plantcell.org/content/plantcell/18/1/40.full.pdf

SCHIRMER, J.; FIELD, J. The cost of revegetation: final report. National Heritage Trust Bushcare Program, 2000. https://www. researchgate.net/publication/240630054_The_Cost_of_Revegetation 
SHINOHARA, T.; MARTIN, E.A.; LESKOVAR, D.I. Ethylene regulators influence germination and root growth of globe artichoke seedlings exposed to heat stress conditions. Seed Science and Technology, v.45, n.1, p.167-178, 2017. https://doi.org/10.15258/ sst.2017.45.1.07

SILVA, A.C.; DAVIDE, L.C.; BRAZ, G.T.; MAIA, J.; CASTRO, E.M.; SILVA, E.A.A. Re-induction of desiccation tolerance in germinated cowpea seeds. South African Journal of Botany, v.113, p.34-39, 2017. https://doi.org/10.1016/j.sajb.2017.07.011

SILVA, R.R.P.; OLIVEIRA, D.R.; ROCHA, G.P.E.; VIEIRA, D.L.M. Direct seeding of Brazilian savanna trees: effects of plant cover and fertilization on seedling establishment and growth. Restoration Ecology, v.23, n.4, p.393-401, 2015. https://doi.org/10.1111/rec.12213

SILVA, T.T.A.; VON PINHO, E.V.R.; CARDOSO, D.L.; FERREIRA, C.A.; ALVIM, P.O.; COSTA, A.A.F. Qualidade fisiológica de sementes de milho na presença de bioestimulantes. Ciência e Agrotecnologia, v.32, n.3, p.840-846, 2008. http://dx.doi.org/10.1590/S141370542008000300021

SIVRITEPE, N.; SIVRITEPE, H.O.; ERIS, A. The effects of $\mathrm{NaCl}$ priming on salt tolerance in melon seedling grown under saline conditions. Scientia Horticulturae, v.97, n.3-4, p.229-237, 2003. https://doi.org/10.1016/S0304-4238(02)00198-X

SMITH, D.M. The practice of silviculture. 8. ed. New York: John Wiley, 1986. 610p.

SUMMERS, D.M.; BRYAN, B.A.; NOLAN, M.; HOBBS, T.J. The costs of reforestation: a spatial model of the costs of establishing environmental and carbon plantings. Land Use Policy, v.44, p.110-121, 2015. https://doi.org/10.1016/j.landusepol.2014.12.002

WALLIN, L.; SVENSSON, B.M.; LÖNN, M. Artificial dispersal as a restoration tool in meadows: sowing or planting? Restoration Ecology, v.17, n.2, p.270-279, 2009. https://doi.org/10.1111/j.1526-100X.2007.00350.x

WANG, W.; VINOCUR, B.; ALTMAN, A. Plant responses to drought, salinity and extreme temperatures: towards genetic engineering for stress tolerance. Planta, v.218, p.1-14, 2003. https://doi.org/10.1007/s00425-003-1105-5

WEN, F.; ZHANG, Z.; BAI, T.; XU, Q.; PAN, Y. Proteomics reveals the effects of gibberellic acid (GA3) on salt-stressed rice (Oryza sativa L.) shoots. Plant Science, v.178, n.2, p.170-175, 2010. https://doi.org/10.1016/j.plantsci.2009.11.006 use, distribution, and reproduction in any medium, provided the original work is properly cited. 